\title{
Karakteristik Sapi Bali Betina pada Dua Gugus Pulau di Provinsi Maluku
}

\section{(The Characteristic of Bali Cattle on two island clusters in Maluku Province)}

\author{
Nurfaizin, Bansi H, Matitaputty PR \\ Balai Pengkajian Teknologi Pertanian Maluku \\ Nurfaizinspt@gmail.com
}

\begin{abstract}
The development of agricultural in Maluku refers to island clusters concept with emphasis the livestock sector in the west seram and south seram islands cluster. In Maluku, most female Bali cattle for breeding. In order to improve performance and reproductive of the cattle its necessary to knowed the qualitative and quantitative characteristics in two islands clusters. This research aims to describing characteristics of qualitative and quantitative from Bali cattle in West Seram and South Seram clusters in the Maluku Region. The material used female Bali cattle aged 2-4 years divided to 62 head in West Seram Island Cluster and 41 head in the South Seram Island Cluster. The collected data were qualitative and quantitative properties then observed descriptively. To determine the differences in quantitative properties of bali cattle on both island clusters used $\mathrm{T}$ Test. The results showed that characteristic of qualitative and quantitative in two island clusters are relatively similar, except significant differences in chest width, in the West Seram Island Cluster at $25.09+5.23 \mathrm{~cm}$ while the South Seram Island Cluster at $23.67+4.06 \mathrm{~cm}$. The characteristics of female Bali cows in the West Seram Island Cluster more potential better production than the South Seram Island Cluster when viewed from the width of the chest.
\end{abstract}

Key words: Characteristic, Bali cattle, island clusters

\begin{abstract}
ABSTRAK
Pembangunan pertanian Maluku mengacu pada konsep gugus pulau dengan menitik beratkan sektor peternakan berada pada Gugus Pulau Seram Barat dan Seram Selatan. Di Maluku, sebagian besar budidaya sapi bali betina adalah untuk pembibitan. Dalam rangka perbaikan performan dan kinerja reproduksi induk perlu diketahui sifat kualitatif dan kuantitatif sapi bali betina pada dua gugus pulau tersebut. Pengkajian ini bertujuan mengetahui karakteristik Sapi Bali betina pada Gugus Pulau Seram Barat dan Seram Selatan yang terdapat di wilayah Maluku. Materi yang digunakan Sapi Bali betina berumur 2-4 tahun sejumlah 62 ekor di gugus pulau Seram Barat dan 41 ekor di gugus pulau Seram Selatan. Data yang diamati yaitu sifat kualitatif dan kuantitatif kemudian diamati secara deskriptif. Untuk mengetahui perbedaan sifat kuantitatif Sapi Bali betina pada kedua gugus pulau dilakukan uji T-Test. Hasil menunjukkan bahwa sifat kualitatif dan kuantitatif pada gugus pulau relatif sama, kecuali menunjukkan beda nyata pada lebar dada, yaitu pada Gugus Pulau Seram Barat

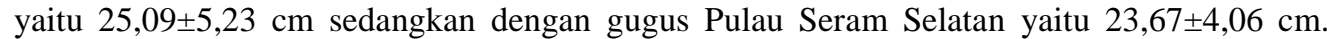
Karakteristik sapi Bali betina di gugus Pulau Seram Barat memiliki potensi produksi lebih baik dibandingkan dengan gugus Pulau Seram Selatan jika ditinjau dari ukuran lebar dada.
\end{abstract}

Kata kunci: Karakteristik, sapi Bali, gugus pulau 


\section{PENDAHULUAN}

Pemanfaatan sapi lokal di Indonesia sebagai asupan pangan sumber protein hewani memberikan kontribusi yang besar. Salah satunya adalah sapi Bali yang merupakan plasma nutfah untuk menghasilkan bibit sapi yang bermutu karena keunggulannya yang tidak dimiliki oleh bangsa sapi lainnya di dunia misalnya memiliki kemampuan dalam memanfaatkan pakan berkualitas rendah yang efisien, angka kesuburan tinggi, tahan terhadap berbagai jenis penyakit, mudah beradaptasi pada berbagai lingkungan, dan masa panen yang cepat. Pada wilayah Indonesia bagian timur termasuk di Maluku sapi yang dipelihara oleh petani tradisional sebagian besar adalah jenis sapi Bali (Latulumamina 2013; Suardana et al. 2013; Hafiz et al. 2018).

Pola konsumsi masyarakat yang lebih menyukai daging segar dibandingkan daging olahan (beku) membuat dominansi perdagangan sapi dalam bentuk ternak hidup. Kebutuhan daging sapi masyarakat perkotaan biasa dipenuhi dari daerah sentra produksi sapi potong sehingga melibatkan perdagangan sapi potong antar daerah (Ilham \& Yusjda 2004). Sapi bali merupakan salah satu bangsa sapi daging lokal yang potensial sebagai penghasil daging (Suranjaya et al. 2010). Kota Ambon sebagai letak Ibukota Provinsi dimana memiliki angka pemotongan ternak sapi kedua tertinggi di Maluku yaitu sebesar 2.650 ekor/tahun (BPSc 2018). Pemenuhan kebutuhan sapi dan produk pertanian lainnya melibatkan interaksi gugus pulau. Jarak antar gugus pulau tersebut sangat berpengaruh dimana semakin bertambah dekat jaraknya maka interaksi akan semakin menarik (Narua 2011). Masing-masing gugus pulau akan memiliki pusat pengembangan wilayah yang dijadikan orientasi bagi kota-kota lainnya sehingga terdapat keterkaitan yang diwujudkan dalam pola interaksi antar pusat-pusat pertumbuhan dan pemukiman pada kawasan tersebut (Wattimanela 2011).

Konsekuensi dari gugus pulau juga diimlementasikan pada bidang pertanian pulaupulau kecil di Provinsi Maluku mengacu pada multi lansekap 12 gugus pulau (Kastanya 2016). Gugus Pulau Seram Selatan dan gugus pulau Seram Barat memiliki banyak kemiripan. Kedua gugus pulau tersebut juga sebagai kawasan peruntukan pertanian lahan kering (komoditas palawija, hortikultura dan umbi-umbian) dan budidaya peternakan di Wilayah Maluku. Salah satu perbedaan spesifiknya gugus pulau Seram Barat sebagai salah satu kawasan budidaya pertanian tanaman pangan lahan basah terdapat di (Perpres RI 2014). Populasi sapi di gugus pulau seram barat dan seram selatan masing-masing adalah 23.261 dan 5.690 ekor (BPSab 2018). Hampir semua kecamatan di Kabupaten Maluku Tengah termasuk yang berada dalam gugus pulau Seram Selatan, memiliki kepadatan populasi sapi dengan kategori rendah sehingga pengembangan populasi sapi masih layak untuk ditingkatkan (Nurfaizin 2014).

Budidaya sapi betina (induk) yang memiliki tujuan pembibitan masih memiliki daya tarik di kalangan petani baik yang dijalankan secara sampingan atau total sebagai mata pencaharian. Usaha pembibitan sapi bali terbukti mampu meningkatkan populasi, penyerapan tenaga kerja dan pendapatan petani (Sonbait et al. 2011). Kegiatan pembibitan merupakan salah satu cara dalam pengembangkan populasi dimana harus ditunjang oleh perbaikan performan dan kinerja reproduksi induk (Hakim et al. 2010). Oleh karena itu informasi dan pengamatan fenotipik sifat-sifat kuantitatif ukuran tubuh dimana membantu dalam memberikan deskripsi dan potensi ternak (Salamena et al. 2007). Karakteristik fenotip adalah suatu hal yang dapat diamati atau terlihat secara langsung warna dan pola warna tubuh, perkembangan tanduk, dan sebagainya (Naufal et al. 2016). 
Ukuran tubuh ternak sangat penting untuk diketahui, pendekatan terhadap hubungan antara satu atau lebih ukuran bagian tubuh ternak dapat digunakan sebagai Pendugaan bobot badan ternak (Tonbesi et al. 2009). Sifat kualitatif seperti warna bulu, bentuk tanduk dan warna kaki merupakan bagian yang penting untuk dikarakterisasi karena dapat digunakan sebagai ciri dari sebuah rumpun (Misrianti et al. 2018).

Informasi karakterisasi sapi Bali yang terdapat di wilayah Maluku masih sedikit untuk ditemukan sehingga menjadi tujuan dalam pengkajian yaitu untuk mengetahui informasi keragaman sifat kualitatif dan kuantitatif sapi bali betina pada dua gugus pulau yaitu gugus pulau seram barat dan seram selatan yang terdapat di wilayah Maluku. Dengan mengetahui informasi karakteristik sapi Bali dapat memberikan gambaran dan perencanaan dalam kegiatan budidaya dan pembibitan sapi Bali pada masa mendatang.

\section{MATERI DAN METODE}

Pengkajian menggunakan sapi lokal ras Bali yang dipelihara dengan sistem ekstensif (umbaran) milik peternak di gugus pulau Seram Barat meliputi Kecamatan Kairatu, Kairatu Barat dan Inamosol yang secara administratif masuk di Kabupaten Seram Bagian Barat serta gugus pulau Seram Selatan meliputi Kecamatan Amahai dan Teon Nila Serua yang secara administratif masuk di Kabupaten Maluku Tengah. Jumlah sampel yang digunakan yaitu sebanyak 62 ekor di Gugus Pulau Seram Barat dan 41 ekor di gugus pulau Seram Selatan. Sampel sapi Bali betina berumur 2-4 tahun yang diketahui berdasarkan melihat susunan perubahan jumlah gigi seri (Torell et al. 2003). Peralatan yang digunakan yaitu kandang jepit sebagai tempat mengukur ternak, pita ukur "rundo" untuk mengukur panjang ukuran tubuh, tongkat ukur dengan skala $0,1 \mathrm{~cm}$ untuk mengukur tinggi gumba, timbangan ternak digital kapasitas $2.000 \mathrm{~kg}$ untuk mengukur bobot badan, pena dan buku untuk mencatat hasil pengukuran.

Data diperoleh dengan cara mengumpulkan data langsung di lapangan dan wawancara dengan peternak. Pengambilan data sampel dilakukan dengan mengikat sapi bali untuk kemudian dimasukkan ke dalam kandang jepit. Selanjutnya sampel diamati karakter kualitatif dan kuantitatif yang dilakukan saat sapi berdiri tegak pada bidang datar. Pengamatan sifat kualitatif berdasarkan sifat luar yang tampak antara lain warna bulu, garis punggung, warna kaos kaki, warna cermin pantat dan tanduk. Karakter kuantitatif meliputi bobot badan dan ukuran tubuh meliputi panjang kepala, lebar kepala, panjang badan, tinggi pundak, lebar dada, dalam dada, lingkar dada (LIPI 2015). Data penelitian karakteristik kualitatif dianalisis dan dikelompokkan berdasarkan distribusi frekuensi. Data kuantitatif yang diperoleh dianalisis secara deskriptif dengan menghitung nilai rata-rata dan standar deviasi pada setiap ukuran tubuh. Untuk mengetahui perbedaan sifat kuantitatif sapi Bali betina pada kedua gugus pulau dilakukan uji $\mathrm{T}$ Test dengan menggunakan bantuan Data Analyze Tool pada Microsoft Office Excel 2016.

\section{HASIL DAN PEMBAHASAN}

\section{Sifat kualitatif}

Karakteristik kualitatif sapi bali betina terdiri dari warna bulu, garis punggung, warna kaos kaki, warna cermin pantat, bentuk tanduk dan warna moncong, disajikan pada Tabel 1. Berdasarkan pengkajian sifat kualitatif pada kedua gugus pulau relatif seragam. Warna bulu sapi bali betina sebagian besar adalah warna coklat kekuningan sedangkan sisanya terdistribusi pada warna merah muda dan coklat muda serta sebagian kecil yang 
lain adalah warna hitam dan coklat tua. Ciri yang lain yaitu warna kaos kaki dan cermin pantat didominasi putih dengan garis batas tegas. Bentuk tanduk yang beragam, namun sedikit sekali yang dijumpai sapi betina yang tidak bertanduk (dugul). Sedangkan warna moncong sebagian besar warna hitam dan belum satupun yang dijumpai warna putih pada lokasi pengkajian sehingga menjadi salah satu penciri di kedua gugus pulau tersebut. Memiliki garis punggung sedang pada gugus pulau seram barat dan seram selatan Memiliki garis punggung tipis.

Tabel 1. Sifat kualitatif sapi Bali di Maluku

\begin{tabular}{|c|c|c|}
\hline \multirow{2}{*}{ Sifat kualitatif (\%) } & \multicolumn{2}{|c|}{ Gugus Pulau } \\
\hline & Seram Barat (\%) & Seram Selatan $(\%)$ \\
\hline \multicolumn{3}{|l|}{ Warna bulu } \\
\hline Merah bata & 17,74 & 19,76 \\
\hline Coklat muda & 20,97 & 19,27 \\
\hline Coklat kekuningan & 50,00 & 51,22 \\
\hline Coklat tua & 4,84 & 2,44 \\
\hline Hitam & 6,45 & 7,32 \\
\hline \multicolumn{3}{|l|}{ Garis punggung } \\
\hline Tebal & 3,23 & 0,00 \\
\hline Sedang & 58,06 & 43,90 \\
\hline Tipis & 38,71 & 56,10 \\
\hline \multicolumn{3}{|l|}{ Warna kaos kaki } \\
\hline Putih, batas tegas & 85,48 & 85,37 \\
\hline Putih, batas tidak tegas & 14,52 & 14,63 \\
\hline \multicolumn{3}{|l|}{ Warna cermin pantat } \\
\hline Putih, batas tegas & 95,16 & 95,12 \\
\hline Putih, batas tidak tegas & 4,84 & 4,88 \\
\hline \multicolumn{3}{|l|}{ Bentuk tanduk } \\
\hline Melengkung ke atas & 45,16 & 51,22 \\
\hline Melengkung ke depan & 40,32 & 36,59 \\
\hline Kecil & 11,29 & 9,76 \\
\hline Tidak ada & 3,23 & 2,44 \\
\hline \multicolumn{3}{|l|}{ Warna Moncong } \\
\hline Hitam & 87,10 & 92,68 \\
\hline Putih & 0,00 & 0,00 \\
\hline Campuran & 12,90 & 7,32 \\
\hline
\end{tabular}

Berdasarkan Kepmentan (2010) bahwa sapi Bali memiliki khas warna kulit merah bata, warna putih pada empat kaki bagian bawah, dimulai dari tarsus atau carpus ke bawah. Pada bagian pantat memiliki warna putih berbentuk oval dengan batas yang jelas. Sedangkan pada bagian punggung terdapat garis belut berwarna hitam. Bentuk tanduk 
meruncing, melengkung ke arah tengah dengan warna hitam. Karakter kualitatif sapi Bali tersebut hampir mendekati kemiripan dengan penelitian Bahary (2017), yaitu memiliki garis punggung sedang, warna kulit sebagian besar coklat kekuningan. Naufal et al. (2016) melaporkan Eksplorasi data tentang identifikasi secara kualitatif merupakan indikator penting untuk dikaji khususnya terkait dengan potensi genetik secara kualitatif.

\section{Sifat kuantitatif}

Pada pengukuran sifat kuantitatif yang diamati adalah bobot badan serta ukuran tubuh meliputi panjang kepala, lebar kepala, panjang badan, tinggi pundak, lebar dada, dalam dada, lingkar dada secara lebih lengkap disajikan pada Tabel 2.

Tabel 2. Rata-rata dan standar deviasi ukuran tubuh sapi Bali betina di Maluku

\begin{tabular}{lcc}
\hline \hline & \multicolumn{2}{c}{ Gugus pulau } \\
\cline { 2 - 3 } Ukuran tubuh & Seram Barat & Seram Selatan \\
& $\mathrm{n}=62$ & $\mathrm{n}=41$ \\
\hline Bobot badan $(\mathrm{kg})$ & $180,30 \pm 24,67$ & $176,73 \pm 23,12$ \\
Panjang badan $(\mathrm{cm})$ & $110,15 \pm 7,42$ & $112,32 \pm 15,52$ \\
Tinggi pundak $(\mathrm{cm})$ & $109,16 \pm 5,2$ & $108,84 \pm 6,04$ \\
Lingkar dada $(\mathrm{cm})$ & $146,79 \pm 11,36$ & $143,93 \pm 10,66$ \\
Lebar dada $(\mathrm{cm})$ & $25,09 \pm 5,23^{\mathrm{b}}$ & $23,67 \pm 4,06^{\mathrm{a}}$ \\
Dalam dada $(\mathrm{cm})$ & $61,96 \pm 7,07$ & $60,22 \pm 9,11$ \\
Panjang kepala $(\mathrm{cm})$ & $36,42 \pm 4,66$ & $33,76 \pm 4,02$ \\
Lebar kepala $(\mathrm{cm})$ & $19,62 \pm 2,62$ & $18,03 \pm 2,16$ \\
\hline
\end{tabular}

Superskrip yang berbeda pada belakang angka dalam baris yang sama menunjukkan beda nyata $(\mathrm{P}<0,05)$

Rata-rata bobot badan sapi bali yang berada pada gugus pulau Seram Barat dan Seram Selatan diperoleh 176,73 hingga 180,30 kg, Panjang badan 110,15 hingga 112,32 $\mathrm{cm}$, tinggi pundak 108,84 hingga 109,16 cm, lingkar dada 143,93 hingga 146,79 cm, lebar dada 23,67 hingga 25,09 cm, dalam dada 60,22 hingga 61,96 cm, panjang kepala 33,76 hingga 36,42 cm dan lebar kepala 18,03 hingga 19,62 cm. Hasil pengkajian ukuran tubuh yang telah dilakukan tersebut memberikan hasil yang relatif sama dengan penelitian Ishak et al. (2015) yaitu tinggi pundak 101,39 hingga 109,44 cm, lingkar dada 138,20 hingga 146,10 cm dan panjang badan 111,60 hingga 119,50 cm.

Rata-rata bobot badan dan ukuran bagian tubuh yang lain di lokasi pengkajian tergolong rendah jika dibandingkan dengan kriteria Kepmentan (2010) bobot badan betina umur 2 tahun adalah $170-225 \mathrm{~kg}$, tinggi badan 105,4-114,4 cm, panjang badan betina 117,2 - 120,0 cm, lingkar dada 158,6 - 174,2 cm. Di sisi lain ukuran bagian tubuh yang didapatkan nilai yang tinggi pada bagian dalam dada sedangkan yang lain cenderung rendah jika dibandingkan dengan Tonbesi et al. (2009) yaitu panjang badan $113,06 \pm 3,48 \mathrm{~cm}$, tinggi pundak $110,00 \pm 4,24 \mathrm{~cm}$, lingkar dada $150,91 \pm 8,53 \mathrm{~cm}$, lebar

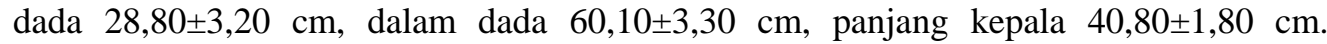
Berdasarkan Latulumamina (2013) bobot badan sapi Bali Betina di pulau Seram Maluku umur 2-4 tahun yaitu 212,42 $\pm 43,99$ hingga $246,17 \pm 67,70 \mathrm{~kg}$. Rendahnya bobot badan 
dan ukuran tubuh tersebut memberikan menjadi peringatan bahwa terdapat potensi penurunan kualitas genetik sehingga performa sapi bali betina yang terdapat di kedua gugus pulau tersebut rendah. Dalam penelitian yang dilakukan oleh Niam et al. (2012) mendapatkan hasil terdapat korelasi antara ukuran-ukuran tubuh terutama pada tinggi pundak, panjang badan dan lingkar dada dengan bobot badan sapi Bali betina. Semakin tinggi ukuran-ukuran tubuh maka akan semakin tinggi pula bobot badan. Menurut Chamdi (2005) penampilan eksterior sapi bali dapat digunakan sebagai indikator kemampuan produksi dan reproduksi.

Berdasarkan uji statistik didapatkan beda nyata pada lebar dada antara sapi Bali Betina di gugus pulau Seram Barat lebih tinggi dibandingkan dengan gugus pulau Seram Selatan yaitu $25,09+5,23 \mathrm{~cm}$ vs $23,67+4,06 \mathrm{~cm}$. Dengan demikian sapi Bali betina yang berasal dari Gugus Pulau Seram Barat lebih berpotensi memiliki produktivitas dimensi tubuh yang lebih besar di bandingkan yang lain. Hal tersebut karena lebar dada memiliki peran dalam perkembangan dimensi tubuh. Faktor yang mempengaruhi lebar dada salah satunya adalah ketersediaan pakan pada agroekosistem Seram Barat yaitu sebagai salah satu kawasan budidaya pertanian tanaman pangan lahan basah dimana memiliki limbah pertanian sebagai pakan dengan kuantitas dan kualitas yang lebih baik dibandingkan Seram Selatan yang hanya sebagai kawasan peruntukan pertanian lahan kering. Berdasarkan Syawal et al. (2013) laju pertumbuhan ukuran tubuh sapi dipengaruhi juga oleh perkembangan lebar dada. Berdasarkan Kleden \& Neobais (2018) kawasan lahan kering memiliki ketersediaan pakan yang tidak merata sepanjang tahun yang didominasi oleh pakan dengan serat tinggi.

\section{KESIMPULAN}

Sapi Bali betina di gugs pulau Seram Barat dan Seram Selatan memiliki sifat kualitatif dan kuantitatif yang relatif sama. Karateristik kuantitatif sapi Bali betina di gugus pulau Seram Barat memiliki lebar dada yang lebih besar dibandingkan dengan gugus pulau Seram Selatan sehingga memiliki potensi produktivitas yang lebih baik.

\section{UCAPAN TERIMA KASIH}

Ucapan terima kasih disampaikan kepada staf Bidang Peternakan di Dinas Pertanian Kabupaten Seram Bagian Barat serta Dinas Perkebunan dan Peternakan Kabupaten Maluku Tengah yang telah membantu dalam pengambilan data di lapangan.

\section{DAFTAR PUSTAKA}

[BPS] Badan Pusat Statistik. 2018a. Kabupaten Maluku Tengah dalam angka 2018. Maluku Tengah (Indonesia): Badan Pusat Statistik Kabupaten Maluku Tengah.

[BPS] Badan Pusat Statistik. 2018b. Kabupaten Seram Bagian Barat dalam angka 2018. Seram (Indonesia) Badan Pusat Statistik Kabupaten Seram Bagian Barat.

[BPS] Badan Pusat Statistik. 2018c. Provinsi Maluku dalam angka 2018. Maluku (Indonesia): Badan Pusat Statistik Provinsi Maluku.

Bahary MAD. 2017. Perbedaan sifat kualitatif dan kuantitatif sapi Bali tidak bertanduk dengan sapi Bali bertanduk [Skripsi]. [Makassar (Indonesia)]: Universitas Hasanuddin.

Chamdi AN. 2005. Karakteristik sumberdaya genetik ternak sapi Bali (Bos bibos banteng) dan alternatif pola konservasinya. Biodiversitas. 6:70-75. 
Hafiz AWM, Hifzan RM, Ariff OMR, Bahtiar AJI, Ashraff ALF. 2018. Comparison of growth pattern for body weight in Brakmas and Bali cattle using non-linear regression models. Mal J Anim Sci. 21:19-28.

Hakim L, Ciptadi G, Nurgiartiningsih VMA. 2010. Model rekording data performans sapi potong lokal di indonesia. J Ternak Tropika. 11:61-73.

Ilham N, Yusjda Y. 2004. Sistem transportasi perdagangan ternak sapi dan implikasi kebijakan di Indonesia. Analisis Kebijakan Pertanian. 2:37-53.

Ishak ABL, Nurhayu A, Ella A, Sariubang M, Rahmawati T. 2015. Seleksi performans induk sapi Bali sebagai upaya pembentukan populasi dasar pada program pembibitan dan pemurnian sapi Bali di Kabupaten Barru Provinsi Sulawesi Selatan. Dalam: Natsir A, Ali HM, Agustina L, Syamsu JA, Syahrir S, Sirajuddin SN, Baba S, Dagong MIA, Hakim MR, et al., penyunting. Prosiding Seminar Nasional Optimalisasi Sumberdaya Lokal Pada Peternakan Lokal Berbasis Teknologi. Makasar (Indonesia): Universitas Hasanuddin. hlm. 59-65.

Kastanya A. 2016. Konsep pertanian pulau-pulau kecil berbasis gugus pulau menghadapi perubahan iklim global di Provinsi Maluku. J Hutan Pulau-Pulau Kecil. 1:1-10.

Kepmentan. 2010. Keputusan Menteri Pertanian Nomor 325/Kpts/OT.140/1/2010 Tentang Penetapan Rumpun Sapi Bali. Jakarta (Indonesia): Kementerian Pertanian.

Kleden MM, Nenobais. 2018. Upaya pendayagunaan limbah pertanian sebagai pakan unggulan musim kemarau di lahan kering. J Pemberdayaan Masyarakat. 3:213-221.

Latulumamina M. 2013. Korelasi antara umur dan berat badan sapi Bali (Bos sondaicus) di Pulau Seram. Agrinimal. 3:35-40.

[LIPI] Lembaga Ilmu Pengetahuan Indonesia. 2015. Panduan pengisian form penampilan fisik. Bogor (Indonesia): Laboratorium Reproduksi, Pemuliaan dan Kultur Sel Hewan. Pusat Penelitian Bioteknologi. Lembaga Ilmu Pengetahuan Indonesia.

Misrianti R, Mustika RP, Ali A. 2018. Keragaman sifat kualitatif dan kuantitatif sapi kuantan pada berbagai tingkatan umur di Kecamatan Benai Kabupaten Kuantan Singingi Provinsi Riau. J Peternakan. 15:55-61.

Naufal F, Setyowati EY, Suwarno N. 2016. Karakteristik kualitatif sapi Pasundan di peternakan rakyat. Student E-Journal. 5:1-13.

Narua LA. 2011. Strategi pengembangan transportasi laut antar pulau dalam rangka peningkatan pembangunan ekonomi daerah di Kabupaten Maluku Tenggara Barat [Tesis]. [Bogor (Indonesia)]: Institut Pertanian Bogor.

Niam HUM, Purnomoadi A, Dartosukarno S. 2012. Hubungan antara ukuran-ukuran tubuh dengan bobot badan Sapi Bali betina pada berbagai kelompok umur. Anim Agric J. 1:541-556.

Nurfaizin. 2016. Potensi daya dukung pakan berbasis agropastural terhadap pengembangan populasi sapi lokal di Kabupaten Maluku Tengah. Dalam: Fadwiwati AY, Anasiru RH, Mantau Z, Zubair A, Masaong AK, Lalio L, Hendayana R, et al., penyunting. Prosiding Seminar Nasional. Gorontalo (Indonesia): Balai Besar Pengkajian dan Pengembangan Teknologi Pertanian. hlm. 725-732.

[Perpres RI] Peraturan Presiden Republik Indonesia. 2014. Peraturan Presiden Republik Indonesia Nomor 77 Tahun 2014 Tentang Rencana Tata Ruang Kepulauan Maluku.

Salamena JF, Noor RR, Sumantri C, Inounu I. 2007. Hubungan genetik, ukuran populasi efektif dan laju silang dalam per generasi populasi domba di Pulau Kisar. J Indones Trop Anim Agric. 32:71-75. 
Sonbait LY, Santosa KA, Panjono. 2011. Evaluasi program pengembangan sapi potong gaduhan melalui kelompok lembaga mandiri yang mengakar di masyarakat di Kabupaten Manokwari Papua Barat. Bul Pet. 35:208-217.

Suardana IW, IM Sukada, IK Suada, Widiasih DA. 2013. Analisis jumlah dan umur sapi Bali betina produktif yang dipotong di Rumah Pemotongan Hewan Pesanggaran dan Mambal Provinsi Bali. J Sains Vet. 31:43-48.

Suranjaya IG, Ardika IN, Indrawati RR. 2010. Faktor-faktor yang mempengaruhi produktivitas sapi Bali di wilayah binaan proyek pembibitan dan pengembangan sapi Bali di Bali. Majalah Ilmiah Peternakan. 13:83-87.

Syawal S, Purwanto BP, Permana IG. 2013. Studi hubungan respon ukuran tubuh dan pemberian pakan terhadap pertumbuhan sapi pedet dan dara pada lokasi yang berbeda. J Ilmu Teknologi Peternakan. 2:175-188.

Tonbesi TT, Ngadiyono N, Sumadi. 2009. Estimasi potensi dan kinerja sapi Bali di kabupaten Timor Tengah Utara, Provinsi Nusa Tenggara Timur. Bul Peternakan. 33:30-39.

Torell R, Bruce B, Kvasnicka B. 2003. Methods of determining age of cattle. Dalam: Conley K. Gund Research and Demonstration Ranch Manager. p. 1-3.

Wattimanela HJ. 2011. Pemetaan sektor transportasi di Provinsi Maluku dengan menggunakan analisis klaster. Dalam: Rusgianto, Hartono, Jailani, Djamilah BW, Mahmudi A, Sugiman, Abadi AM, Dhoriva UW, Sahid, et al., penyunting. Prosiding Seminar Nasional Matematika dan Pendidikan Matematika. Yogyakarta (Indonesia): Universitas Negeri Yogyakarta. hlm. 314-331. 